
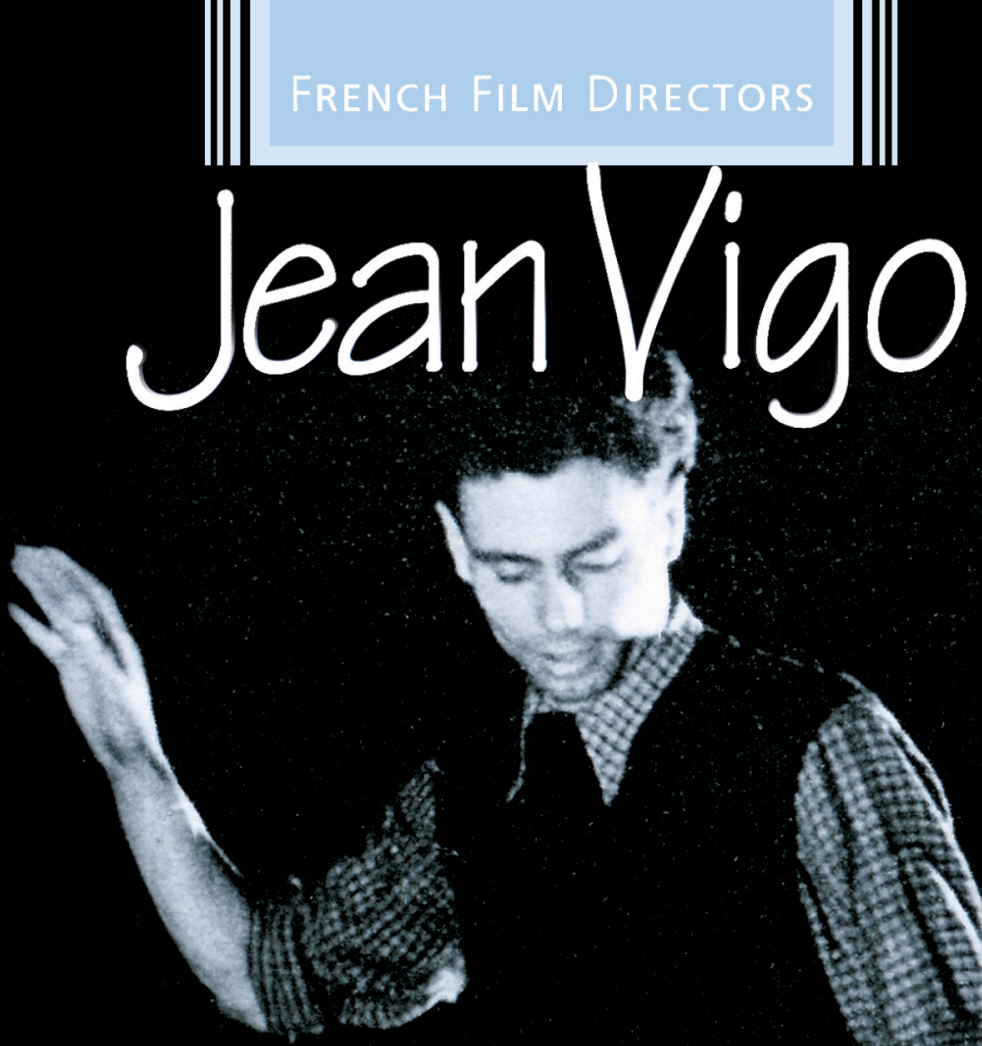

MICHAEL TEMPLE 


\section{Jean Vigo}

\section{MANCHESTER 1824}

Manchester University Press 


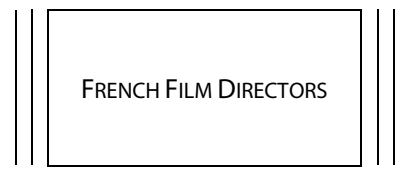

DIANA HOLMES and ROBERT INGRAM series editors DUDLEY ANDREW series consultant

Jean-Jacques Beineix PHIL POWRIE

Luc BesSOn SUSAN HAYWARD

Bertrand Blier SUE ARRIS

Robert Bresson KEITH READER

Leos Carax GARIN DOWD AND FERGUS DALEY

Claude Chabrol GUY A USTIN

Claire Denis MARTINE BEUGNET

Marguerite Duras RENATE G ÜNTHER

Georges Franju KATE INCE

Jean-Luc Godard D OUGLAS MORREY

Diane Kurys CARRIE TARR

Patrice Leconte LISA DOWNING

Louis Malle HUGO FREY

Georges Méliès ELIZABETH EZRA

Jean Renoir MARTIN O'SHAUGHNESSY

Coline Serreau BRIGITTE ROLLET

François Truffaut DIANA HOLMES AND ROBERT INGRAM

Agnès Varda ALISON SMITH 


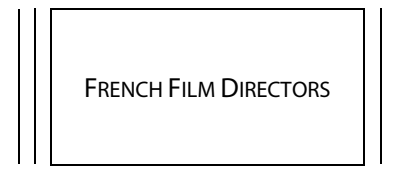

\section{Jean Vigo}

\section{Michael TempLe}

\section{MANCHESTER 1824}

Manchester University Press 
Copyright $\odot$ Michael Temple 2005

The right of Michael Temple to be identified as the editor of this work has been asserted by her in accordance with the Copyright, Designs and Patents Act 1988.

Published by Manchester University Press

Altrincham Street, Manchester M1 7JA, UK

www.manchesteruniversitypress.co.uk

British Library Cataloguing-in-Publication Data

A catalogue record for this book is available from the British Library

Library of Congress Cataloging-in-Publication Data

A catalog record for this book is available from the Library of Congress

ISBN: 0719086330 paperback

ISBN 13: 9780719056338

First published 2005 by Manchester University Press

The publisher has no responsibility for the persistence or accuracy of URLs for any external or third-party internet websites referred to in this book, and does not guarantee that any content on such websites is, or will remain, accurate or appropriate. 